\title{
I Can Do Better Than That! ${ }^{1}$
}

\section{David Homel Montreal, Québec}

Where did my life as a writer and literary translator begin? With this event: I remember a certain high school English teacher of mine, Bill Cantrell by name, pointing at me one time in class and declaring, "You come from a home where a foreign language is spoken."

Probably it began earlier, but that classroom judgment is as good and representative a place to start as any other.

I was not exactly mortified by the teacher's comment, but I wasn't too happy either. A foreign language in the home was a kind of handicap. Picture this: a school full of kids whose parents or grandparents came from elsewhere, southern or eastern Europe most of them, yet no one could own up to the fact, and having this "heritage," as it's called now, was like having a crazy uncle locked up in the attic. Don't forget, this was Chicago, in the glory days of the American ideology of the melting pot.

I remember asking the good Mr. Cantrell why he thought that, why he had said what he'd said. "It's the way you talk," he told me. I didn't pursue the issue.

The guy was right, I had to admit it. I did have a foreign language in the home, and it was my parents' native language: Yiddish. Or almost-native, if such a thing can be. The existence of this crypto-language - it was more or less "crypto" because it was more or less hidden, depending on the moment and the degree of stress - was probably my beginning as a writer, and as a translator. Mind you, a few other things came into play as well, because if every kid who had a foreign language spoken in his or her home became a translator and/or a writer, the competition would be even fiercer than it already is.

A "crypto-language," from the Greek kryptos, meaning "hidden, covered or secret," is exactly that: a language that is hidden. Now, there are many reasons why a language must be hidden; many such reasons are political, and have to do with the oppression of one group by another. I saw this first-hand in rural Louisiana, with French, for example. But here, what interests me is not the out-and-out repression of the means of expression of one group by a more powerful one. I'm more concerned with the processes of forgetting in individual and groups of individuals, and how that works over time. And most of all, how this "forgetting" - willful or otherwise - leaves its traces on the way of speaking and writing that individuals

1 An earlier version of this paper was delivered as the keynote address for the 2010 St. Jerome's Day Conference at the University of Alberta. 
will eventually end up using. If this sounds a bit abstract, do not fear. I will be giving examples from my own work.

What that high school teacher said has stuck with me like a stone in my shoe. First as a source of shame, then as an immense territory to be mined - "mined" in the sense of exploited, but "mine" in the sense of anti-personnel device isn't entirely off-target either. The teacher was on to something, though he didn't exactly put it the way I'm going to. Once you have lived young in and around a foreign language in your home, a language you don't understand, or do understand and pretend you don't, or don't want to acknowledge - or all those things and more - then naïve and innocent self-expression, spontaneous, so-called "natural" self-expression goes out the door. And with it goes childhood, in a way. You no longer trust how you talk, or how anyone else does, for that matter.

Though I'm not much for literary criticism as applied by writers to themselves and their own works - I'd rather leave that to the real critics - I have to own up to the facts. My novels are full of hidden languages (crypto-languages), and those languages always cause trouble, or are the markers of some forgotten (or almost forgotten) trauma. In Rat Palms, a novel of mine from way back in 1992 (and praised by the Edmonton Journal, so thank you if you're out there), physical trauma leads to the greater trauma of remembering something publically that you wished you'd forgotten better. When Zeke Justice, a baseball player, gets hit in the head with a pitch, after he comes to, he finds himself talking, part of the time, in French, even if he is living in Savannah, Georgia, where that language is definitely not an asset. What happens is this: the baseball brings on an attack of incontinent nostalgia (a very beautiful phrase I stole from the world of neurology), which means that Zeke Justice remembers something in spite of himself, something he didn't know he had: the French language. And because of that acting out - he begins talking French in the hospital - he is forced to recover the fact that he is not quite American, but a Franco-American or, actually, behind that, a French Canadian.

The fun doesn't stop there. In Sonya \& Jack, a novel from 1995, Jack Gesser and Sonya Friedman leave Chicago to go adventuring into Stalin's Russia to help build socialism. Gesser, originally a Russian, speaks the language, whereas Sonya, a Hungarian, does not. Through his ability to speak, Gesser belongs to Russia, and the Stalinist system swallows him up. Sonya Friedman, ignorant of the language of her oppressor, manages to survive. Sometimes, knowing a language can get you into big trouble.

Of course, in real life, it doesn't always work this way. It's interesting to note the comment by the Spanish-born writer Jorge Semprún who was imprisoned in the Nazi death camp of Buchenwald as a Communist. One of the keys to surviving the camps, he wrote in Literature or Life (L'écriture on la vie in the original language), was knowing German, the torturer's language. It's obvious that what causes complications and sometimes trouble for characters in books can be immensely useful in real life. And it is equally obvious that the

This work is licensed under a Creative Commons Attribution 3.0 License 
trouble and complication is also a wonderful source of inspiration for writing - if not the main source, in my case, of both translation and writing. So let us praise our curses and complications!

In my novel Get on Top, an itinerant Jewish peddler named Gazarra, loosely based on my late uncles, achieves surprising status and authority in the rural south of the United States: "In proper houses and in shacks alike, blacks and whites both would beg him to speak Hebrew. 'What?' he would ask them. He feared a trap. 'What do you want me to say?' 'Say God's name," they urged him, 'Say God's name in God's own language."' Of course, then Gazarra has to explain to these good people that God's name is unnamable, and to his surprise the country folk he is hoping to sell stuff to are delighted by the riddle.

In The Speaking Cure, the question of crypto-language is both political and psychiatric. The novel is set in Belgrade, in the former Yugoslavia, towards the end of the Bosnian war, in 1995. The language called Serbo-Croatian is disappearing because no one wants to speak the enemy's tongue any more; it has split into Serbian, Croatian and Bosnian, which are all the same language with some regional variations. So much for the political side. The "affect" side is more important for the novel's hero Aleksandar Jovic, who works as a clinical psychologist in Belgrade, a real front-line position. He knows most if not all of his patients are lying to him with the stories they tell, but that does not bother him in the least. At the very start of the book, he states, "I never objected if a client told me a lie, or concocted a story for my benefit. I granted them the right to lie... Lies didn't bother me in the least. I listened to them daily, and never challenged them. Behind every lie lay the truth. Better than that, every lie told the truth." Here, the hidden language is one of disorder created by the particular trauma that the client/narrator is telling. This is something we're all acquainted with in our daily lives.

In my latest novel Midway, Ben Allan accuses his aging father Morris of having another language crouching at all times behind his English, like a sort of court jester ready to make mischief and disrupt what he wants to say. Morris retorts by maintaining that Ben too has been tarred by that particular brush - for how could it be otherwise, since he is, after all, his father's son? A foreign language, according to Morris' somewhat humorous speculations, is like one of those Old Testament curses from Deuteronomy and Leviticus, like sleeping with your sister: the family, the clan will be punished for seven generations.

Were I to re-read myself, I'd have to conclude that we're all better off not having two or more languages, and that having parallel and conflicting languages running in your head at the same time can only be a source of trouble. Not a very Canadian point of view, n'est-ce pas? And certainly not a point of view I've adopted as my own in my own life. But if I wrote those things, somewhere in me I must believe it. I must believe that crypto-languages - and many of us have them - inevitably force their way to the surface in an "upward drive of the repressed" kind of movement, and that this process can be psychically damaging for the

This work is licensed under a Creative Commons Attribution 3.0 License 
individual, especially if he or she has up until then refused to acknowledge the hidden thing. I guess that, when it comes to languages, I subscribe to the classical Freudian model.

Going further back into classroom memories would take me to that fateful morning that, in a certain way, put me on the pathway that led to this room where I'm happy to be speaking to you. One day, our teacher Mrs. Crapple (I'm not making the name up) entered the room and in that irritating "Be-nice-boys-and-girls" voice of hers, announced that we were going to be given the opportunity to learn a foreign language. This news was met with a collective groan from the group. I'll always remember how she handled that reaction. "No, class," she answered. "A real foreign language."

Real? I think we all understand what a real foreign language was. It was not Polish or Czech or some dialect from Campobasso or Molise; it was not a language of immigration. And that unspoken assumption turned out to be true. Mrs. Crapple gave us a choice between German, Spanish and French. German was out for obvious family reasons involving the burning of villages and slaughter of villagers in Lithuania in World War II (not the language's fault, of course). As for Spanish, we had already begun learning it thanks to the waves of Mexican immigrants and their kids who had begun showing up in our schools, more each new September than the previous year. I chose French. It was a clean language, unbesmirched by immigration, a luxury language that spoke of refinement, prestige, worldliness and all the things we were not. Plus it was the language of poetry. Some of us more bookish kids were would-be poets, and we wanted to be Arthur Rimbaud and Paul Verlaine, sometimes both at the same time (which meant we would have had to shoot ourselves, since Verlaine shot Rimbaud, albeit half-heartedly). We liked the poète-voyou (delinquent poet) image that let us simultaneously be small-time criminals and sensitive guys, and we were counting on French to help us reach that lofty and somewhat absurd plateau.

And here we are today. If you are wondering, you won't be surprised to note that nowhere did Canada appear in our world view. We did not know that people spoke French in Canada. Asking us where Canada was would have been an unfair question, since Americans are not particularly gifted when it comes to geography. But we did have some gifts: all the kids who entered that enriched language learning program in high school went on to become something a little better than ordinary.

That program helped me learn French, and allowed me to become a translator of literary works. So thank you very much after all, Mrs. Crapple, wherever you are now. As I began to work in translation towards the end of the 1970s, I considered that craft as an apprenticeship for writing. This statement might cause some discomfort for people who think that translation is, in itself, an end. A final accomplishment. That may well be true for some people. There are many excellent translators - let me name two into-English ones: Sheila Fischman and Nigel Spencer - who to my knowledge are happy to be working as translators (and sometimes teachers), and feel fulfilled by that literary activity. I was never one of those.

This work is licensed under a Creative Commons Attribution 3.0 License 
(Actually, I suspect that even my friend Sheila, though she swears it's not true, is probably hiding a manuscript somewhere in a drawer in her desk.) I now see that I came to translation through a desire to write. Since I did not grow up in the English-French vortex of Canada, since when I went to university, translation programs did not exist (whereas writing programs did; we can think of the famous MFA program at the University of Iowa), I came to translation as a way of studying language, and how it was used in novels that had been published, because that was what I wanted for myself.

At the beginning, I saw, and continue to see even today, translation as a kind of sneaky voyeurism. When you translate a novel (I am speaking of fiction here, my domain almost entirely, though I do translate some non-fiction), you get to - actually, you are forced to - slip around behind the sets and the stage dressing and the special effects and see the very structures of the book at their most naked. The result is often this: a book that reads well, when you are a reader, can be a pain to translate because the sentences don't hold together, there is no necessity from one sentence, or proposition, to the next, the paragraphs are not coherent in their movement from one to the next, the rhythm is like an ice-skater with dull blades. I always marvel at how I, as a reader, can read right past those pitfalls, whereas I as a translator get stuck on them, like a canoeist on a snag. I have gotten caught on a couple of snaggy books in my career. Since then, I have learned to be more of a discerning and critical evaluator.

Of course, at times like that, when you are in a snag position, you put down the book you are translating and exclaim, "I can do better than that!" And perhaps you can. For those translators who are interested in the processes of writing, there is much to be learned, and it usually comes out as a mixture of humility - I must serve this book - and hubris - I can do better than that. We should consider that both statements are true. Just as we should consider that my other favorite and apparently outrageous statement is true, which is this: the translation should be better than the original. That's what I told my French translator Sophie Voillot when she embarked on my novel Midway. I assumed that she did not think I was engaging in sophistry or jokes. I assumed she understood that, as a late-coming reader of the manuscript, she had the chance to correct what was wrong with the story.

And correct she did. I had one character say in Midway that he was like Athena who burst fully formed from Zeus' rib... Of course Adam was the rib thing, whereas Athena burst fully formed from Zeus' head. There is nothing translators like more than correcting "their" author's mistakes. This is a form of revenge that writers should accept gratefully, since it does lead to a better book - that is, as long as that sense of revenge is not fueled by outright hostility. That can happen too.

But let's not forget that the translator who secretly or not so secretly wants to be a writer can make a mess of things. This is the kind of translator who thinks he or she knows better what's right for the book, and makes the necessary modifications to "improve" on the

This work is licensed under a Creative Commons Attribution 3.0 License 
original work. I confess: I did that at the beginning. If only my author had written the book the way he should have... Then I got wise and took a very good piece of advice. Write your own damn book ifyou're so smart.

Of course, as we compare writing and translating as creative activities, and the occasional comedy between the two, there is a big element missing in the comparison, like the famous elephant in the room. Novels are not made of words. They are not even made of sentences and paragraphs either, no matter how well sculpted they may be. Novels are made of necessities, the absolute need I have to write this book, to tell this story, without which I will perish as a writer and a human being. The absolute need to know how this story will turn out, and the absolute certainty that the only way to know is to write it. So, though many translators who are also good stylists may think that they can do better than these clunky sentences and limping paragraphs they are being called upon to translate, if they are not inhabited by a necessity to tell a story whose end they must discover, then they don't have much of a leg to stand on when it comes to criticizing the work before them that they must serve as its translator.

In the end, that's the difference between translating and writing. We write the story to find out how it will end. This is the writer's mantra: why do I write this story? To discover how it will turn out. When we translate, that story has already ended. We cannot intervene to make it end in another way, no matter how hard we may wish. Therein lies some of the translator's frustration and restlessness. In my translation work, I "cheat" by not reading the book I am called upon to translate ahead of time - ever - because I am attempting to recreate the writer's experience: he or she did not know how it would end before he or she wrote it, so I want to take that same uncertain journey. My translation is my reading of the book. This method - I am not the only one to practice it; my co-translator Fred Reed does the same thing - creates more revision work, especially at the beginning, but it retains the freshness of the work. In that way, albeit somewhat artificially, I am trying to turn translation into something like the act of writing.

I recently discovered that I have an ancestor, an originator in this practice: Phil Stratford. Apparently he promoted the same way of working, though I did not know it at the time I was "inventing" this approach. And so my invention is actually a form of imitation without knowing it. But as they say, there is nothing new under the sun.

I have wondered over the years whether, since I am interested in crypto-languages as a thematic in fiction, whether I am manifesting, without knowing it, that same interest as a literary translator. It's hard to tell, just as it's hard to tell what you are writing about in a novel until you've gone and done it, and spilled the beans for all to read. But in one case, a long, long time ago, I probably did turn to a language hidden in me in order to translate a very singular, violent little book. I'm talking about Jacques Renaud's Le Cassé from 1964, that I called Broke City in English. I went back in time and "channeled" (as they used to say in the 
days of Shirley MacLaine) the rough brand of English we used to use in Chicago. I quite deliberately turned East End Montreal into the Southwest Side of Chicago, and used a kind of "dirty white boy" speech for the characters in this altogether nasty little novella. And I even wrote a preface about doing that. Really, I just wanted the joy of seeing my kind of hometown English on the page of a book published in my linguistically lonely new country.

The casualty of being a translator is innocent reading. Even when I'm reading something for pleasure - that is, not for pay - often a sentence will make me stop and I will imagine the frustrations and challenges it would force upon me were I its translator. And, worse, sometimes I read myself in English as my translators would, having to puzzle out the mess I've made of their day's work. Sometimes I think that translation has ruined my life as a reader because I can no longer read innocently. Then I realize that this process is simply the extension of the foreign-language inner jester that I described early.

Of course, all is not anguish. Sometimes there is play. That is, playing with anguish, my own and other people's. I ruined my French translator Christine Leboeuf's life (my translator at the time, that is) by writing about baseball in my novel Rat Palms. (Of course, North American writers are always torturing European translators with their tales of that sport.) When I was finishing Sonya \& Jack, I realized I had not included any baseball scenes to torment her with, mainly because most of the novel takes place in the Soviet Union. But how could I deprive Christine of that pleasure? So I returned to the manuscript and wrote a scene that takes place in the courtyard of the KGB building in Moscow (it wasn't called the KGB back then, but that's another story), where a group of political prisoners who had lived in the United States for a time are playing a primitive form of baseball with a frozen potato. This scene, that started as an inside joke between Christine and me, actually led me to figuring out the fate of one of the book's main characters, who will be pushed from a window and fall into that courtyard during the game, thereby ruining it for the players.

Over the years, on and off, I have taught translation at Concordia University in Montreal as a part-time instructor. I have told my students until I'm blue in the face that translation leads to everything, as long as you abandon it along the way. Most of my students are in the program just to get a job once they exit school, so they don't particularly want to listen to my Zen-style riddles like that one. But I am being serious. We should consider translation as one of the arts that uses language as its medium, its way of communication, and in that manner it is similar to writing novels or non-fiction or screenplays or, God help us, advertising copy, or journalism or anything else. The debate about whether you can teach creative writing yes, no or both of the above - is exactly the same as the one about whether you can teach literary translation. Yes, you can learn some chops, as they say in jazz, in a translation program, you can learn how to use certain tools and helpers, but basically the ear and sensitivity for language has to be developed in the same way as the creative writer does it. If I ran the zoo, to quote Dr. Seuss, I'd put literary translation classes in the same department 
as creative writing workshops. I think the two fields are naturals together, and complement each other. I don't know how it's done here, but I can tell you that at Concordia, unfortunately no one shares my idea. At least no one with any power and influence. Too bad, because the literary translator's ear and the fiction-writer's ear develop in the same way: by reading and by listening and by combining our own thoughts with what is going on in the world, and staging the conflict between the two.

I live in Montreal, a city that is a kind of laboratory and observation post for cryptolanguages and for people who are running two or more languages simultaneously in their head. Of course, you could say that any big city is full of people with crypto-languages; no doubt Edmonton is full of such people. You could say that this phenomenon is not limited to big cities with their traditional immigrant populations, and I'd have to agree with you. No doubt the experience of crypto-languages is different in the United States and Canada, to name the two countries where I have spent long periods of time. And no doubt it is different now in the US than it was when my dear Mr. Cantrell and Mrs. Crapple made their pronouncements; the expression "melting pot" is now often accompanied with an ironic sneer in the United States. The "melting pot" has been replaced by the "roots trip," the latter being both a fashion, and therefore a commercial enterprise, and also a quest for identity, a quest to give our identities more dimensionality - to find out where we came from.

But getting back to Montreal, I remember that, before I settled in there - if indeed I am settled at all - I used to visit the city, staying at my friend Ray Chamberlain's apartment may he rest in peace. A word about Mr. Chamberlain: he was one of Canada's best French to English translators, working most notably on Victor-Lévy Beaulieu back when VLB was a real threat as a writer. Chamberlain unsuccessfully tried to reconcile his native language - his Savannah, Georgia version of English - with the English of English Canada and the French of French Canada. One morning, leaving his apartment for a journalistic errand, I ran into a neighbor woman on the landing. I introduced myself and, to justify my English accent in French, I said I lived in Toronto and was visiting here. "Oh," she said in a friendly way, "it must be hard for you to be here and speak French." I answered her without thinking: "No harder than it is to speak English in Toronto." The good woman shook her head at the nonsensical thing I had said and hurried down the stairs to begin her day's work.

I thought about what I had said. It did sound strange. And worse, it sounded impolite. But it was true, in the way that we sometimes say true things when we are not paying attention. I lived in Toronto then: an English-speaking town. I spoke English. I should feel comfortable there. But that was not the case. Every time I opened my mouth, a misunderstanding ensued. One small example: I tend to use the imperative (command) form a lot, and this was considered dreadfully impolite in Toronto. Whereas in Montreal, a seemingly French city, and one obsessed with language at the time, the differences between languages were objectified. The foreignness I was living with and in was clear for all to see 
TranscUlturAl, vol.4.1 (2011), 5-14.

bttp:/ / ejournals.library.ualberta.ca/index.php/TC

and hear. As it turned out, Montreal was the perfect place for someone with my sevengeneration language afflictions. A long time ago, at the beginning of the 1990s, in a novel I had a character say: "The telephone rings in my flat in Montreal, Canada. A city made for the expatriate, the perplexed individual hanging between the Old World and the New. A city of minorities, where each one tries to out-minority the other in a comical ballet. Astonishingly, this is all done in an atmosphere of good humor."

And that still is true. 
TranscUlturAl, vol.4.1 (2011), 5-14.

bttp:/ / ejournals.library.ualberta.ca/index.php/TC

\section{REFERENCES}

Homel, David. Midway. Markham, ON: Cormorant Books, 2010.

—. The Speaking Cure. Vancouver: Douglas \& McIntyre, 2003.

—. Get on Top. Toronto: Stoddart Books, 1999.

—. Sonya \& Jack. New York: HarperCollins, 1995.

—. Rat Palms. New York: HaperCollins, 1992.

Renaud, Jacques. Broke City. Trans. David Homel. Le Cassé (1964). Toronto: Guernica Editions, 1983.

Semprún, Jorge. L'écriture ou la vie. Paris: Gallimard, 1994. 